\title{
Lobbying Is a Biologically Necessary Transaction Cost in a Democracy
}

\author{
Stephen P. Magee1, Kwang-Yeol Yoo² \\ ${ }^{1}$ University of Texas at Austin, Austin, USA \\ ${ }^{2}$ Financial Supervisory Service, Government of Korea, Seoul, South Korea \\ Email:magee@mail.utexas.edu, jaesuyoo@naver.com
}

How to cite this paper: Magee, S.P. and Yoo, K.-Y. (2019) Lobbying Is a Biologically Necessary Transaction Cost in a Democracy. Modern Economy, 10, 1589-1612. https://doi.org/10.4236/me.2019.106105

Received: March 11, 2019

Accepted: June 27, 2019

Published: June 30, 2019

Copyright $\odot 2019$ by author(s) and Scientific Research Publishing Inc. This work is licensed under the Creative Commons Attribution International License (CC BY 4.0).

http://creativecommons.org/licenses/by/4.0/

\begin{abstract}
We explain why lobbying is a biologically necessary transaction cost in a democracy. We use lobbying for trade protection to illustrate because we have controls for other effects by using the Young and Magee [2] general equilibrium international trade model with 2 goods, 2 factors, 2 lobbies and 2 political parties, all maximizing in a game theoretic equilibrium. Our empirical estimates show that protectionist lobbying costs are low: 0.8 of one percent in our advanced countries and 0.2 of one percent for the US. There are political economy explanations for lobbying and corruption: money creates power and power creates money. There are biological explanations for lobbying: humans are carnivores and compete for power like animals in dominance hierarchies. Using both explanations, competitive lobbying is an equilibrium outcome. Our data focus on capital intensive exports compared to import-competing industries in 8 non-EC OECD countries in 1965 and 1986 and factor intensities of production from wage and capital earnings in 3-digit level ISIC data.
\end{abstract}

\section{Keywords}

Tariffs, Lobbying, Democracy, Dominance Hierarchies, Biological Metaphors, Rent Seeking

\section{Introduction}

Among the numerous advantages promised by a well-constructed Union, none deserves to be more accurately developed than its tendency to break and control the violence of factions... By faction I [mean] a number of citizens united by some interest, adverse to the aggregate interests of the community... Enlightened statesmen will be able to adjust these clashing interests and render them all subservient to the public good.... The Federal 
Constitution forms a happy combination; the great and aggregate interests being referred to the national, the local and particular to the state legislatures. James Madison, Federalist Paper \#10

We use lobbying over trade protection to explain why lobbies are an inevitable transaction cost in democracies. The proof is statistical: every democracy in the world has both tariffs and lobbies. The general equilibrium tariff model in this paper uses empirically calibrated simulations to measure the transactions costs of lobbying in the US and other advanced countries. Lobbying and redistributive policies in all Western democracies are not fatal weaknesses-they are just obvious transaction costs when people fight each other over power and control. This paper also discusses the political strengths and weakness of democracies and the economics that drive them.

There are two reasons why lobbies are necessary in democracies. The first is political economy and the second is biological.

First, the political economy reason for lobbying is described in Magee, Brock and Young's Black Hole Tariffs book [1]: money creates power and power creates money. Politicians are analogous to market makers who set prices on the trading floors of stock exchanges. Policies are the prices that politicians set to clear the market as determined by supply and demand. Special interests demand policies like tariffs and voters supply them, as brokered by the protectionist politicians. If voters strongly oppose undesirable policies, then market clearing special-interest policies will be low. The policy will be set high and distortionary if the lobby is strong. In equilibrium, lobbies channel funds to politicians to offset the negative electoral effects of bad policies.

We use the Young and Magee [2] general equilibrium political economy model of endogenous protection in this paper to estimate country lobbying transactions costs. This model is a $2 \times 2 \times 2 \times 2$ model with 2 goods (exportable and importable), 2 factors (capital and labor), 2 factors (capital and labor) and 2 political parties (pro-capital and pro-labor) with all of the 8 actors mathematically maximizing their self-interest. Voters choose rationally and probabilistically by voting more for parties with resources and less for parties with more distortionary policies.

Political economy equilibria reflect the terms trade between organized groups and voters. The evolution of group power is reflected in history. The economic interest of the American founding fathers is reflected in our constitution and the laws of that generation. The organized interests of the time were shopkeepers and merchants. Jefferson pushed the other founders to approve universal education that created a large and prosperous middle class that could support the small firm economy of the founding fathers. This successful uniting of special interests and the general interests of the country are described in a paper on the Madison paradox in Federalist Papers No. 10 by Christopher Magee and the senior author [3]. James Madison said that the greatest challenge in writing the American Constitution was the problem of special interests. Madison studied over 150 constitutions of ancient and contemporary nations, but found that not 
a single nation had solved the problem of special interests.

The second reason for the necessity of lobbying is biological. Magee's [4] work on bioeconomics shows that both capitalism and democracy are Darwinian. We argue in this paper that lobbying is biologically unavoidable in democracies. Humans are carnivores and compete like animals in dominance hierarchies.

The economically strong emerge with capitalism and the politically organized rule in a democracy. The paradox of capitalism is that economic order emerges invisibly out of seeming chaos based on nothing more than individual self-interest. This is Adam Smith's invisible hand at work. Schumpeter said capitalism is renewed when technology changes lead to waves of creative destruction that wipe out old industries and create new ones. This leads to shifts in the tectonic plates of interests groups that underly democracy. New political groups arise and with them, new leadership. These evolutionary changes enhance country fitness, economic and political.

Bioeconomics gives insights into political economy. It shows that animals are either territorial, which is an animal form of private property (dogs and deer) or hierarchically organized (chicken pecking orders), like human politics and law. The pyramid of nature has carnivores at the top who consume herbivores who consume herbs who depend on worms, etc. Human capitalists are territorial while politicians are hierarchical. Territorial capitalists negotiate economic deals (win-win) while hierarchical politicians compete vertically as they ascend to power (win-lose). The political economy of democracies resemble nature's pyramid of nature. Political competition leads the powerful to dominate the weaker. In political competition, particularized groups lobby and thus gain at the expense of generalized ones. Large well-organized lobbies dominate disorganized ones and voters.

Magee [4] argues that trait group selection theory is one biological metaphor that yields intuitive insights for both lobbying and political economy. This theory is about altruistic leader signal birds sitting at the top of trees that warn the rest of the flock that predators are present. These leader birds are frequently killed by predators, which does not sound adaptive for the specie. The seeming paradox of the higher mortality of the signal birds was resolved by Dawkins who argued that it is not the altruistic leader bird that needs to survive but rather its gene through the higher survival rates of the leader bird's offspring living in the tree. The intuitive explanation of trait group adaptation is that signal birds have higher mortality rates but that groups with more signal birds expand faster than groups without them. When groups expand faster than the leaders die off, then leadership fitness is enhanced because the "selfish" leader genes expand through the offspring.

The selfish gene mathematics yields another paradox when comparing capitalist countries like the US with other nations. It is possible for the proportion of selfish individuals in every state in the US to increase and yet the proportion of selfish individuals in the entire US to decrease. How? Because states with a lower proportion of selfish (leader-type) individuals will grow faster than states with 
higher proportions of selfish individuals.

Advanced nation states with low internal conflict should expand economically faster than other nations. On this subject, homogeneous Scandinavian states and economically successful states come to mind. Studies have shown that nations which trade with each other are less prone to war, so win-win economics is a unifying force. Among nation states, groups selection is at work. Nations with efficient governments and institutions are more adaptive. The most efficient countries will have lower costs.

We do not argue here that Western capitalism and democracy is the best for all emerging markets. Witness the very mixed results of US economic and political intervention in the Middle East this century. The senior author of this paper learned from Paul Samuelson in graduate school decades ago that central planning can improve economic development using turnpike theorems [5]. Economic development can be enhanced by government policy under benevolent despots that fosters investing at turnpike speed to rapidly achieve high levels of capital per person. The virtual state Singapore is a case in point.

Madison and the framers of the Constitution decided that since they could not eliminate special interest activity, they would raise its cost. Their solution was to disperse power geographically between the nation and the states in a federal system and disperse it functionally at the national level across executive, legislative and judicial branches. To succeed, a special interest would have to capture all three branches of the national government and a number of the largest state governments. This constitutional architecture with its high barriers to special interest entry is one reason why ours and other estimates are so low for protectionist lobbying expenditures in the United States. In additional to this political determinant of special-interest lobbying, there are economic drivers.

Be aware that trade protection is only one way to protect domestic industries. Endogenous policies are fungible so countries can switch to prohibitions on foreign companies producing and selling domestically. Japan and Germany have done this for years.

Figure 1 shows that Japan and Germany, the two export miracle countries of the last century, protected their domestic producers by simply excluding foreign firms from producing in there via opaque rules on domestic production by foreign firms.

Our goal in this paper is to measure the transactions costs of protectionist trade policy lobbying. We find that they are low in the democracies studied and only a fraction of one percent in the US. This is explained by the exogenous determinants of endogenous tariffs: higher magnification effects in capital returns in capital intensive export industries compared to labor returns in importable-competing ones. Advanced country tariffs are low in advanced countries because of high capital to labor country factor endowment ratios. Capital is more economic powerful and a politically powerful force for freer trade.

Our simulation and empirical estimates find that protectionist lobbying in the advanced countries is only 0.8 of one percent of GDP and for the US it is 0.2 of 




Figure 1. Foreign companies as a $\%$ of manufacturing.

one percent of GDP. These low numbers suggests that the transactions costs of protectionist lobbying are low. One explanation is that while magnification of wages with respect to product prices (e.g. the effectiveness of tariffs) have increased in recent years, the magnification of capital returns with respect to product prices have increased even more. The other is that tariffs are low because of more intense lobbying by capital against protection and increased capital to labor country factor endowments through time. These factors reduce the payoff to protectionist lobbying.

This introduction has given a necessary background on the political economy of a democracy. Section 2 is a review the literature on lobbying and how it relates to the model in the paper. Section 3 presents the theoretical model followed by Section 4 with empirical results and analysis. Section 5 summarizes the paper with ten conclusions and three policy recommendations.

We have three policy recommendations for the US. First, enact constitutional reform to prevent predatory redistributive lobbying. Second, impose costs on lobbyists faster than they can evade them. Third, lawyers should be prohibited from lobbying. Washington DC has 10 times more lawyers per resident than New York, the highest state in lawyers per resident.

\section{Literature Review}

There are four major approaches to lobbying and the political economy of trade protection and tariffs. The first is the rent seeking literature started by Tulloch [6] indicating that all of the producers' surplus might be wasted in lobbying using a partial-equilibrium model. Krueger [7] estimated that 7\% of Indian GNP was absorbed in rent-seeking while $15 \%$ of Turkish GNP was lost to rent-seeking over import licenses. While these early lobbying estimates may have been accurate for deve- 
loping countries, they are far higher than the numbers for advanced countries today.

The second approach to trade protection lobbying is the special-interest lobbying approach adopted in this paper. It started with Brock and Magee [8] followed by Young and Magee [2] in general equilibrium and the by the comprehensive Magee Brock and Young [1] MBY book of 1989. MBY showed empirically that the factor endowments of countries are the largest empirical driver of trade protection. In advanced countries, the scare factor labor typically lobbies for protection while capital lobbies for free trade, following traditional Stolper Samuel and Heckscher Ohlin trade theory. MBY examine the factor endowments of countries and they reveal the dominant economic interests and the direction that lobbying and governments take.

Along these lines, Magee and Magee [9] have shown that the land-abundant countries of Latin America industrialized and educated their populations more slowly and fought economic development because this was inimical to the economic interests of the abundant factor, the land-owning class. The land-poor countries of Asia advanced because they were not inhibited by the parochial economic interests of land owners. The economic drag generated by landed special-interest is reflected in evidence that land-abundant countries grow more slowly. The series of bad governments in Latin America dominated by land owners explains the high government turnover rates. For example, Bolivia had 190 government turnovers in a 160 -year period. Good economic policies generate government stability, a luxury good enjoyed by high income countries.

There is a third "minimalist" literature led by Becker [10] and Wittman [11] arguing that democracy will be economically efficient if there are cheaper redistributive policies to fund parties and inform voters, then they should have replaced tariffs. Becker (1983) argued that it will be political competition will drive democracies to redistribute wealth in least-cost ways. With so many competing democracies in the world, a Becker-Wittman view is that party competition should evolve toward least-cost or "surviving" redistributive policies. Protection is such a policy. However, our estimates here of low lobbying costs for protection supports a Becker-Wittman view, at least for the advanced countries we study.

A fourth literature follows Robert Barrow [12] who analyzed the empirical determinants of democracy. He argues that the positives of democracy are its limits on government power and policies while the negatives are rich to poor redistributions and the power of interest groups. That is, the rich gain through special-interest lobbying but they lose through progressive taxation. When these two effects are offsetting, a democracy would be redistributively neutral. But, it would still be plagued by the price inefficiencies and the resource costs of special-interest policies.

Barro's two weaknesses of democracy are clear. Voters can exploit the rich because of their numbers through taxation. But special interests can dominate the average voter because of superior organization. It would be interesting to know the democracies in which these two effects are just offsetting, yielding redistributive neutrality. 


\section{Theoretical Model}

Our research design is to estimate the Young Magee [2] general-equilibrium model of tariffs and total trade protection based on the factor intensities of production in exportables in import-competing production and simulates the factor income maximizing levels of lobbying by both capital and labor levels of lobbying to contribute to a protectionist and a pro-export political parties. The parties are assumed to maximize their probabilities of election, trading off the positive effects of campaign lobbying funds against negative voter aversion to redistributive policies.

Our econometric estimates apply Young and Magee [2] and Magee, Brock and Young's [1] empirical insights to panel data consisting of 8 countries over the 22 years from 1965-1986. Their model has a national economy with fully endogenous politics and two goods, two factors, two lobbies and two political parties. Following the stylized facts in the advanced countries, the labor-intensive importable good is supported politically by tariff protection funded by campaign contributions of labor resources to the protectionist party by a labor lobby. All of the actors (factor markets, goods markets, lobbies and political parties) display explicit maximizing behavior. Voters choose parties probabilistically, increasing their likelihood of voting for parties with more resources and decreasing their likelihood for parties with more distortionary special-interest policies.

The basic drivers of endogenous democracy are factor endowments, voter rationality and production technology. Specifically, the exogenous variables in our model are country factor endowments of the primary factors of production (each country's capital/labor endowment ratio); the elasticity of the probability of party election with respect to special-interest policies relative to campaign contributions; and the factor intensities of production for importables relative to exportables.

We assume Cobb-Douglas production functions that exhibit constant returns to scale and there are no factor intensity reversals. The country is small and faces an exogenous international price $\mathrm{P}$, which is the price of good 2 in terms of good 1. However, domestic special-interest politics generate trade distortions so that the domestic price Q can differ from P. Q can be higher than P because of the tariff but lower than $\mathrm{P}$ because of the export subsidy.

$$
\begin{aligned}
& Q=P T / S=\left[P_{2}(1+t)\right] /\left[P_{1}(1+s)\right] \\
& S=(1+s) \\
& T=(1+t)
\end{aligned}
$$

where $s$ : the ad valorem export subsidy rate

$t$. the ad valorem tariff rate

$P$ : world product price ratio $=P_{2} / P_{1}$

Given nonspecialized production, the usual factor price equalization theorem implies that the equilibrium wage and rental rates depend only on $Q$ and are independent of factor endowments. However, with endogenous politics, factor re- 
turns exhibit increasing returns to factor endowments: as the capital endowment of a country increases, the pro-capital party provides capital with a higher export subsidy. The higher export subsidy more than offsets the normal diminishing returns to capital, so that capital returns increase with country capital-labor endowment ratios.

Assume that the capital and labor lobbies make direct contributions $K$ and $L$ of the their factor to their favored party. This paper considers only countries for which net exports are more capital-intensive relative to imports. The pro-capital party's policy is to subsidize exports of the capital-intensive good 1, while the pro-labor party's policy is to raise the domestic price of the labor-intensive good by a tariff (or other restriction) on imports of good 2.

Assume that each lobby chooses its political contributions to maximize the expected utility of a representative owner of the corresponding factor, while each party chooses its policy in order to maximize its probability of election. Assuming vigorous party competition, each party Stackelberg leads its own lobby, but adopts Nash behavior toward the other party and its lobby, while each lobby adopts Nash behavior toward the other three players. All four players internalize voter behavior and the behavior of economic agents. We assume that the procapital party Stackelberg leads the capital lobby and the pro-labor party Stackelberg leads the labor lobby, with the pro-labor party supporting a tariff to attract labor contributions and the pro-capital party supporting an export subsidy to attract capital contributions.

Let $\mathrm{W}$ and $\mathrm{R}$ be the wage and rental rates. Since good 2 is relatively labor intensive, the Stolper-Samuelson theorem implies that $\partial W / \partial Q>0$ and $\partial \mathrm{R} / \partial Q<0$. The pro-capital party's policy is to set a domestic price of $P / S$ (e.g., by a subsidy on exports of good 1), which is more capital-intensive, while the pro-labor party's policy is to set a domestic price of PT (e.g., through a tariff on imports of good 2).

It is also assumed that the probability of victory by the pro-capital party is $\pi=\pi(K, L, S, T)$ where $\pi$ is increasing in $K$ and $T$ and decreasing in $L$ and $S$. Young and Magee (1986) suppose that each lobby chooses its political contributions in order to maximize the expected utility of a representative owner of the corresponding factor, while each party chooses its policy in order to maximize its probability of election. Assume that the capital lobby's choices are made as if made by a representative individual who owns $K_{0}$ units of capital and has an indirect utility function, $V_{R}=V_{R}\left(Q, I_{R}\right)$ where $I_{R}$ is his or her income. $K$ is the amount of capital devoted to politics. $K$ is chosen to maximize expected utility, i.e., the lobby maximizes its expected utility. The capital owner takes account of the impact of the election on his cost of living because $Q$ appears independently in his indirect utility function. The representative labor owner owns $L_{0}$ units of labor and has an indirect utility function, $V_{W}=V_{W}\left(Q, I_{W}\right)$, where $I_{W}$ is his or her income. $L$ is the amount of labor devoted to politics and is chosen to maximize the laborer's expected utility. Let $K^{*}(L, S, T)$ and $L^{*}(K, S, T)$ be the 
optimal policies of the two lobbies. Assume that $K_{S}^{*}>0$ and $L_{T}^{*}>0$, i.e., if a party proposes a domestic price more favorable to the lobby that it leads, then it attracts more resources from that lobby.

Since the pro-capital party is a Stackelberg leader with respect to the capital lobby and adopts Nash behavior toward the other players, it maximizes its probability of victory by maximizing $\pi\left(K^{*}(L, S, T), L, S, T\right)$ with respect to $S$. Similarly, the pro-labor party maximizes its probability of victory by minimizing $\pi\left(K, L^{*}(K, S, T), S, T\right)$ with respect to $T$. Let the optimal policies of the two parties be $S^{*}(L, T)$ and $T^{*}(K, S)$ respectively. The action of each player in the political game depends on the actions of two or three of the other players, as expressed by the reaction functions $K^{*}(L, S, T), L^{*}(K, S, T), S^{*}(L, T)$ and $T^{*}(K, S)$. An equilibrium is a set of mutually consistent actions $\left(K_{e}, L_{e}, S_{e}, T_{e}\right)$ satisfying $K_{e}=K^{*}\left(L_{e}, S_{e}, T_{e}\right), L_{e}=L^{*}\left(K_{e}, S_{e}, T_{e}\right), S_{e}=S^{*}\left(L_{e}, T_{e}\right)$, $T_{e}=T^{*}\left(K_{e}, S_{e}\right)$.

Suppose that the production functions for goods 1 and 2 are Cobb-Douglas. With a suitable choice of units, the unit cost functions of the two industries can then also be written in the Cobb-Douglas form,

$$
C_{1}(R, W)=R^{\alpha} W^{1-\alpha} \text { and } C_{2}(R, W)=R^{\beta} W^{1-\beta}
$$

where $\alpha, \beta$ are constants such that $0<\beta<\alpha<1$. The numeraire is the more capital-intensive good 1 . If the domestic price of good 2 is $Q$, then in a nonspecialized equilibrium, the wage and rental rates are determined by the zero-profit conditions in the two industries, $1=R^{\alpha} W^{1-\alpha}$ and $Q=R^{\beta} W^{1-\beta}$. The equilibrium factor prices are:

$$
W=Q^{N} \text { and } R=Q^{-M}
$$

where $N \equiv \alpha /(\alpha-\beta)$

$$
M \equiv(1-\alpha) /(\alpha-\beta)
$$

Suppose that the representative owners of capital and labor are risk neutral and have Cobb-Douglas utility functions. Hence, their indirect utility functions have the form:

$$
V_{R}\left(I_{R}, Q\right)=I_{R} Q^{-\gamma}, V_{W}(I Q)=I_{W} Q^{-\delta}
$$

where $I_{R}, I_{W}$ are the incomes of the respective factor owners and $0 \leq \gamma, \delta \leq 1$. By (2), $I_{R}=\left(K_{0}-K\right) Q^{-M}$. Therefore, the utility of the capital lobby when the domestic price is $Q$ is $V_{R}=\left(K_{0}-K\right) Q^{-m}$, where $m \equiv M+\gamma$. Similarly, the utility of the labor lobby is $V_{W}=\left(L_{0}-L\right) Q^{n}$, where $n \equiv N-\delta$.

Since $1>\alpha>\beta>0$, we have $m, n>0$. Thus an increase in $Q$ harms the capital lobby and benefits the labor lobby, as implied by the Stolper-Samuelson theorem. By (3), combinations of income $I_{R}$ and commodity price $Q$ such that $I_{R} Q^{-\gamma}$ is fixed will yield the same utility for the capital owner. Hence, $Q^{\gamma}$ can be seen as a cost of living index. $Q^{-m}=Q^{-M} / Q^{\gamma}$ can be interpreted as the "real" return to capital: the return $Q^{-M}$ in terms of the numeraire, adjusted by the cost of living index $Q^{\gamma}$. Similarly, $Q^{n}$ is the real return to labor. 
The parameters $m$ and $n$ are, respectively, the elasticities of the real returns to capital and labor with respect to the commodity price $Q$. They measure the sensitivity of the lobbies to changes in relative product prices and hence to the political outcome.

Suppose that the function $\pi(L, K, S, T)$-giving the pro-capital party's probability of election-has the logit form. Thus, the pro-capital party's odds of victory, $\Phi$, is a log-linear function of the explanatory variables:

$$
\log \Phi=\log [\pi /(1-\pi)]=\varepsilon+\kappa \log K-\lambda \log L-\sigma \log S+\tau \log T
$$

where $\kappa, \lambda, \sigma, \tau$ are positive constants. For the sake of simplicity, assume that the elasticities of the electoral odds with respect to the resources $K$ and $L$ are unity, so that $\kappa=\lambda=1$. We also assume that $\varepsilon=0$. This yields the probability of election for the pro-capital party as $\pi=1 /\left(1+L S^{\sigma} / K T^{\tau}\right)=K T^{\tau} /\left(K T^{\tau}+L S^{\sigma}\right)$ when $\sigma=\tau$ is also imposed.

This ensures that $\pi=1 / 2$ when $K=L$ and $S=T$.

Thus the capital lobby solves:

$$
\max _{K\left(0<K<K_{0}\right)} e(K)=\left(K_{0}-K\right)\left\{\left[K T^{\tau}\left(P S^{\sigma}\right)^{-m}+L S^{\sigma}\left(P T^{\tau}\right)^{-m}\right] /\left[K T^{\tau}+L S^{\sigma}\right]\right\}
$$

while the labor lobby solves:

$$
\max _{L\left(0<L<L_{0}\right)} f(L)=\left(L_{0}-L\right)\left\{\left[K T^{\tau}\left(P S^{\sigma}\right)^{n}+L S^{\sigma}\left(P T^{\tau}\right)^{n}\right] /\left[K T^{\tau}+L S^{\sigma}\right]\right\}
$$

The reaction functions of the two lobbies are as follows. Let:

$$
K(L, S, T)=\left(L S^{\sigma} / T^{\tau}\right)\left\{\left[\left(1-\left(S^{\sigma} T^{\tau}\right)^{-m}\right)\left(1+K_{0} T^{\tau} / L S^{\sigma}\right)\right]^{1 / 2}-1\right\}
$$

The optimal policy of the capital lobby is: $K^{*}(L, S, T)=\max (0, K(L, S, T))$. Let:

$$
L(K, S, T)=\left(K T^{\tau} / S^{\sigma}\right)\left\{\left[\left(1-\left(S^{\sigma} T^{\tau}\right)^{-n}\right)\left(1+L_{0} S^{\sigma} / K T^{\tau}\right)\right]^{1 / 2}-1\right\}
$$

The optimal policy of the labor lobby is: $L^{*}(K, S, T)=\max (0, L(K, S, T))$.

1) The first order condition determining the optimal pro-capital policy $S$ is:

$$
1+m+m S^{\sigma} L / K_{0} T^{\tau}-\left(S^{\sigma} T^{\tau}\right)^{m}=0
$$

2) If:

$$
m>1
$$

or:

$$
m=1 \text { and } L<K_{0}\left(T^{\tau}\right)^{2},
$$

then (8) is satisfied by a unique positive value of $S$ which also satisfies the second order condition for the problem. If:

$$
m<1 \text { and } L<K_{0}\left(T^{\tau}\right)^{2} m(1-m)^{(1-m) / m}
$$


then (8) can have two solutions but only the one in the interval

$$
0<S<\left\{K_{0}\left(T^{\tau}\right)^{(1+m)} / L\right\}^{1 /(1-m)}
$$

satisfies the second order condition.

3) If, in addition:

$$
\left\{\left(T^{\tau}\right)^{m}-1-m\right\}\left(T^{\tau}\right) K_{0} / m<L
$$

then the solution $S$ to (8) defined in (B) is greater than 1 and is the optimal pro-capital policy $S$. However, if neither (9), (10) nor (11) holds or if (12) is violated, then the optimal pro-capital policy is free trade, i.e. $S=1$.

The optimal pro-labor tariff policy $T^{*}$ can be obtained from (8) through (12) by replacing $m$ with $n$, interchanging $K$ and $L$ and interchanging $S^{\sigma}$ and $T^{r}$.

The set of interior solutions in the model can be characterized in terms of the solution to the following equation. For $m>0$ and $n>0$, the following equation in $r$ :

$$
1=\frac{\left\{1-(1+(m / \sigma)) r^{-m}\right\}^{1 / 2}}{1-r^{-m}}+\frac{\left\{1-(1+(n / \tau)) r^{-n}\right\}^{1 / 2}}{1-r^{-n}}
$$

has a unique solution $r_{e}(m, n)>1$. Let

$$
\begin{gathered}
a(m, n) \equiv-1+\left(1-r_{e}^{-m}\right) /\left\{1-(1+(m / \sigma)) r_{e}^{-m}\right\}^{1 / 2} \\
b(m, n) \equiv-1+\left(1-r_{e}^{-n}\right) /\left\{1-(1+(n / \tau)) r_{e}^{-n}\right\}^{1 / 2} \\
c(m, n) \equiv(m / \sigma) /\left(r_{e}^{m}-(m / \sigma)-1\right) \\
d(m, n) \equiv(n / \tau) /\left(r_{e}^{n}-(n / \tau)-1\right)
\end{gathered}
$$

Suppose that:

$$
1 / r_{e}<(d / b c) K_{0} / L_{0}<r_{e}
$$

Then the country has a unique political-economic interior equilibrium $\left(K_{e}, L_{e}, S_{e}, T_{e}\right)$ given by:

$$
\begin{gathered}
K_{e}=K_{0} a / c \\
L_{e}=L_{0} b / d \\
S_{e}=\left\{\left(K_{0} / L_{0}\right) r_{e}^{\sigma} d / b c\right\}^{1 /(\sigma+\tau)} \\
T_{e}=\left\{\left(L_{0} / K_{0}\right) r_{e}^{\tau} c / a d\right\}^{1 /(\sigma+\tau)}
\end{gathered}
$$

If (18) is violated, then the system has no interior equilibrium.

It follows that the elasticity of $T_{e}$ with respect to the county's factor endowment ratio $L_{0} / K_{0}$ is $1 /(\sigma+\tau)$. Thus, if the voters become more sensitive to the distortions proposed by either party ( $\sigma+\tau$ becomes higher), then the equilibrium tariff becomes less sensitive to the endowment ratio. An increase in $\sigma$ and $\tau$ will decrease the equilibrium levels of distortions and the equilibrium propor- 
tions of resources devoted to politics.

Notice that

$$
r_{e}=S_{e} T_{e}=\left(1+s_{e}\right)\left(1+t_{e}\right)
$$

where $r_{e}$ is the equilibrium product of the distortions. Since $r_{e}>1$, condition (18) for an interior equilibrium will certainly be satisfied for a range of values of $K_{0} / L_{0}$.

\section{Empirical Results}

\subsection{Model Setting}

We are explaining protectionist lobbying protectionist tariffs using a general-equilibrium model, We incorporate the factor intensities of production in exportables in import-competing production and simulate the factor income maximizing levels of lobbying by both capital and labor levels of lobbying to contribute to a protectionist and a pro-export political parties. The parties are assumed to maximize their probabilities of election, trading off the positive effects of campaign lobbying funds against negative voter aversion to redistributive policies.

The parameter inputs to the model are the country factor endowment $\mathrm{K}_{0}, \mathrm{~L}_{0}$; the factor price elasticities $m$ and $n$; the responsiveness of voters to resources used by the parties ( $\kappa=\lambda=1)$; and the responsiveness of voters to the policy positions of the parties on the export subsidy and the tariff, $\sigma$ and $\tau^{1}$. Note that the equation numbers from here skip around and back to the text above.

Since some parameters like $\sigma$ and $\tau$ are not observable, our research strategy is to: 1) use available country-specific variables such as factor endowments, factor price elasticities and the tariff rate $^{2}, 2$ ) estimate basic unobserved parameters and 3) calculate the endogenous political and economic variables of concern by using obtained parameters. Specifically,

1) Country-specific exogenous variables include:

Labor-capital factor endowment ratios $\left(L_{0} / K_{0}\right)$ and factor intensities of production in exportables and importables $(\alpha, \beta)$. By implication, country-specific exogenous variables include the factor price magnification elasticities $(m, n$, $m / \sigma, n / \tau)$

2) The negative elasticity of electoral odds with respect to tariffs ( $\tau$ ) and export subsidies $(\sigma)$ are estimated by running an iterative regression of the tariff Equation (22). However, the utility parameters are assumed to be constant and the same across the country, i.e., $\gamma=\delta=0.5 .^{3}$

${ }^{1}$ The world price $\mathrm{P}$, which is one of the exogenous variables in this model, does not influence the equilibrium levels of endogenous variables, a result special to the Cobb-Douglas model. When production functions are Leontief, for example, then $\mathrm{P}$ does affect the equilibrium values. See Magee [15], Brock and Young (1989, ch. 10-13) for detailed discussions of the Leontief model and its properties.

${ }^{2}$ Since the focus is import protection we do not use the export subsidy Equation (21).

${ }^{3}$ It turns out that the factor price magnification elasticities $(m, n)$ are not affected much by the changes in the utility parameters since $\mathrm{M}$ and $\mathrm{N}$ are large enough and utility parameters are constrained between 0 and 1 . 
3) Country-specific endogenous variables include: ${ }^{4}$

The policy product of the tariff and the export subsidy, $r=(1+s)(1+t)$, where Equation (13) can be re-written

$$
1=\frac{\left\{1-(1+(m / \sigma)) r^{-m}\right\}^{1 / 2}}{1-r^{-m}}+\frac{\left\{1-(1+(n / \tau)) r^{-n}\right\}^{1 / 2}}{1-r^{-n}}
$$

and the tariff in (22) can be re-written ${ }^{5}$

$$
T_{e}=\left\{\left(L_{0} / K_{0}\right) r_{e}^{\tau} c / a d\right\}^{1 /(\sigma+\tau)}
$$

and the fraction of capital devoted to lobbying

$$
\begin{aligned}
& K_{e} / K_{0}=a / c \\
& =\left[-1+\left(1-r_{e}^{-m}\right) /\left\{1-(1+(m / \sigma)) r_{e}^{-m}\right\}^{1 / 2}\right] /\left[(m / \sigma) /\left(r_{e}^{m}-(m / \sigma)-1\right)\right]
\end{aligned}
$$

and the fraction of labor devoted to lobbying

$$
\begin{aligned}
& L_{e} / L_{0}=b / d \\
& =\left[-1+\left(1-r_{e}^{-n}\right) /\left\{1-(1+(n / \tau)) r_{e}^{-n}\right\}^{1 / 2}\right] /\left[(n / \tau) /\left(r_{e}^{n}-(n / \tau)-1\right)\right]
\end{aligned}
$$

\subsection{Data and Country Selection}

Since the model is designed to explain the determination of trade policy in a representative democracy, we restrict the coverage of countries to OECD countries. We further narrow down the countries of interest to countries for which exports are more capital-intensive than import-competing industries because the model above is also developed for a country exporting capital-intensive goods. Twelve countries satisfy this criterion out of 23 OECD countries in 1965. Factor intensities are defined in terms of the shares of capital income and labor income in value added of each industry.

Value added, wage and salary as labor income are available in 3-digit level of ISIC (International Standard Industrial Classification) classification from Industrial Statistics Yearbook. Corresponding industry trade flow data, on the other hand, are available in 4 or 5-digit SITC (Standard International Trade Classification) from International Trade Statistics Yearbook. Trade flow data are concorded to ISIC classifications ${ }^{6}$.

To calculate the factor intensities of net-exporting and import-competing industries, we aggregate up the data on industry factor shares by weighting them by the industry's share of total net exports (net imports) after classifying industries into net-exporting and import-competing sectors. That is,

\footnotetext{
${ }^{4}$ It also includes the probability of election of the protectionist party, $1-\pi=1 /(1+\mathrm{a})$, which is not a focus here.

${ }^{5}$ The tariff even though it is endogenous to the model. We use the tariff data to obtain other unobservable parameters $(\sigma, \tau)$ in an iterative regression and simulation context. It is implicit in our approach that the observed tariff rate is at its equilibrium value.

${ }^{6}$ For a concordance between the SITC and ISIC, see United Nations [13], "Classification of Commodity by Industrial Origin-Links between the SITC and ISIC", Statistical Papers: Series M, No. 34, Rev. 1.
} 


$$
\alpha=\sum_{i} \alpha_{i}{\frac{(\text { netexport })_{i}}{\sum_{j}(\text { netexport })_{j}}}^{7}
$$

where $i, j=3$-digit ISIC industries and $\alpha_{i}=$ capital share in net exporting industry $i$.

In a similar fashion, $\beta$ is calculated. Appendix 1 reports factor shares by country in 1965 and 1986. Aggregate tariffs are obtained by dividing customs revenue by the value of imports. Customs revenue and import data come from Mitchell [14]. Data on capital per labor are available from Penn World Table 5.6 by Summers and Heston (1994).

The next two subsections deal with the estimation of unobserved parameters and therefore other endogenous variables. First, we pool the data from 1965 to 1967 and use an iterative ordinary least squares method after assigning initial values for unobserved parameters in the first stage. Secondly, we estimate a fixed-effects model with year dummies for 1965-1986.

\subsection{Analysis: Iterative OLS Estimation: Pooled Data for 1965-19678}

The procedure of estimating unobserved parameters consists of: 1) running a regression of the endogenous tariff Equation (22), 2) solving the Equation (13) for $r$ and 3) running another regression of (22) using updated data.

First, taking the log of (22) results in

$$
\ln (1+t)=1 /(\sigma+\tau) \ln \left\{\left(L_{0} / K_{0}\right) c / a d\right\}+\tau /(\sigma+\tau) \ln r
$$

Assuming symmetry $(\sigma=\tau)$ in (24) yields the following equation to estimate $\sigma$ and $\tau^{2}$ :

$$
\{\ln (1+t)-0.5 \ln r\}=1 /(\sigma+\tau) \ln \left\{\left(L_{0} / K_{0}\right) c / a d\right\}
$$

Since solving (13) for $r$ and obtaining values for $a, c$, and $d$ require a prior knowledge of $\sigma$ and $\tau^{10}$, we iterate after assigning arbitrary initial values for $\sigma$ and $\tau$ in the first round. That is, we assume $\sigma=\tau=1$. Then we solve the nonlinear Equation (13) for $r^{11}$. Once we have the $r^{2}$ s for each country, a, $c$ and $d$ in Equation (14) are calculated.

Running an OLS regression ${ }^{12}$ of (25) produces the coefficient on the right-

\footnotetext{
${ }^{7}$ This scheme tends to discriminate against non-traded sectors or domestic-oriented sectors. Another deviation from the above model, which is implicit in this formula, is that goods are imperfect substitutes across countries. According to the model, we should not observe cross-hauling of the same categories of commodities across borders.

${ }^{8}$ The European Community (EC) established a "customs union" which adopts a common tariff policy against non-member countries by July of 1968 . Therefore, we do not extend our data beyond 1967.

${ }^{9}$ We may allow $\sigma$ and $\tau$ to differ. However, it is hard to justfy why they would differ. Thus we proceed with the assumption of symmetry throughout the paper.

${ }^{10}$ Strictly speaking, the solution for $\mathrm{r}$ in Equation (13) requires the production parameters ( $\alpha$ and $\beta$ ), the utility parameters ( $\gamma$ and $\delta$, which are assumed to be 0.5 ) and the voter responsiveness parameters $(\sigma$ and $\tau)$. The first two are known. A similar argument applies to values for a, b, $\mathrm{c}$ and $\mathrm{d}$ in Equation (14).

${ }^{11}$ To solve the nonlinear Equation (14), GAMS (solver: MINOS5) is used.

${ }^{12} \mathrm{We}$ include a constant term for the regression.
} 
hand variable, which is equal to $1 /(\sigma+\tau)$. The second round estimation begins with a new $\sigma$ and $\tau$ from the above OLS regression. We iterate until we obtain a stable regression coefficient (or voter responsiveness parameters) in the tariff Equation (25).

In this specific case, a consecutive regression produces a stable coefficient around 0.1 (or implied $\sigma=\tau=5$ ) after the 2 nd round.

Table 1 reports the iteration results. The estimate of 5.0 for $\tau$ indicates a high negative elasticity of voter response at the tariff equilibrium. For example, if the protectionist party raised our tariff variable $T=(1+t)$ by about $5 \%$ (e.g., 1.01 to 1.05 then), $\tau=5.0$ implies that the party will have to raise $25 \%$ more funds just to maintain its existing probability of election. In short, voters display rationality in their responsiveness to distortionary trade policies.

Given that $\sigma=\tau=5$, it is straightforward to see how the endogenization of the political environment within the model modifies elasticities of wages and rental rates with respect to relative product prices, i.e., magnification elasticities. The "economic" elasticities measure the responsiveness of factor returns in the absence of an endogenous political system. These are represented by $m$ and $n$. However, the elasticities at the political equilibrium are much lower due to the negative effect of special interest policies on probabilities of election. Table 2 reports the magnification elasticities at the country mean.

We then estimate lobbying expenditures over trade policy as a percent of the country GDP. The procedure is as follows. Column H and I from Appendix 2 denote the equilibrium fractions of capital and labor devoted to lobbying in the manufacturing sector according to equations $\left(19^{\prime}\right)$ and $\left(20^{\prime}\right)$. Column $\mathrm{K}$ and $\mathrm{L}$ are weighted shares ${ }^{13}$ of capital and labor, respectively. Thus column $\mathrm{O}$ indicates

Table 1. Estimated voter responsiveness: 1965 (an average of 1965-1967).

\begin{tabular}{rcc}
\hline & Regression Coefficient & Implied $\sigma($ or $\tau)$ \\
\hline 1st round & 0.068 & 7.35 \\
2nd round & 0.102 & 4.90 \\
3rd round & 0.100 & 5.02 \\
4th round & 0.101 & 4.93 \\
5th round & 0.098 & 5.10 \\
\hline
\end{tabular}

Table 2. Magnification Elasticities (1965).

\begin{tabular}{ccc}
\hline & Partial (Economic) & Political (General) Equilibrium \\
\hline Country mean & & \\
Rentals $(K)$ & $m \equiv(1-\alpha)(\alpha-\beta)+\gamma=15.53$ & $m / \sigma=3.11$ \\
Wages $(L)$ & $n \equiv \alpha /(\alpha-\beta)-\delta=16.2$ & $n / \tau=3.24$ \\
\hline
\end{tabular}

${ }^{13}$ For example, $\alpha$ (capital share in net-exporting sector) and $\beta$ (capital share in import-competing sector) are weighted by net export or net import volume of each industry to obtain a representative capital share. 
the sum of capital and labor lobbying expenses in the manufacturing sector as a percent of total GDP. Manufacturing as a fraction of GDP is reported in column P. Openness, as the sum of exports and imports divided by GDP, is reported in column $\mathrm{Q}$ in order to capture the intensity of lobbying over trade policy. The lobbying estimates as a fraction of GDP in column $\mathrm{W}$ equal the numbers in column V multiplied times 0.4 based on Lee and Magee's estimate of 60 percent free riding in protectionist lobbying based on estimates across 175 US industries.

Summing up, the fraction of GDP devoted to lobbying over trade policy = $\left(K_{e} / K_{0} *\right.$ weighted capital share $+L_{e} / L_{0} *$ weighted labor share $) *(\mathrm{Mfg} / \mathrm{GDP}) *$ (openness) $*$ (non free riding).

The last column contains lobbying estimates as a percent of GDP for each country. These estimates range from $0.14 \%$ to $2.26 \%$. Ironically, the country with our lowest estimate at only $0.14 \%$ of GDP is Turkey, which Krueger (1974) estimated had $15 \%$ of GDP devoted to lobbying in her classic paper on rent seeking. On average, we find that $1.0 \%$ of GDP was expended on lobbying in 1965. This is an upper bound since the model assumes no free riding within lobbies. See Appendix 2 for procedure and data details.

We provide the correlation matrices for variables of major concern in Appendix 4. As expected, the "economic" determinant of the tariff (i.e., labor-capital ratio) is significantly correlated with the tariff rate. The "political" determinant (i.e., $\left.\ln \left(\mathrm{r}^{\tau} \mathrm{c} / \mathrm{ad}\right)\right)$ is also significantly correlated with the tariff rate. The level of GNP per capita in 1965 is significantly negatively correlated with the level of the tariff. Tariffs fall as countries develop because country labor-capital factor endowment ratios fall and hence, the political power of labor, which tariffs protect.

The statistical results obtained so far are based on the iterative OLS methods for pooled data for 1965 (averaging 1965-1967). There are two implicit assumptions underlying this approach. First, it is assumed that political technology is the same across countries. Second, factor shares from 1965 are used for the analysis and are assumed to be constant through 1967. Third, there is no consideration of how trade policy responds to changes in other variables over time.

\subsection{Analysis: Fixed-Effects Model Estimation with Panel Data (1965-1986)}

In this subsection, we extend the regression model by relaxing the assumptions of identical political technology across countries. A panel of data for non-EC member OECD countries (8 countries) during 1965-1986 are used for this purpose. We take the mean value of factor shares for 1965 and 1986 and assume that it applies to all the time periods of concern.

Besides including country dummies in the regression model, we also include year dummies for 1970-1986. This idea aims at mitigating the prominence of non-trade barriers in post-1970 periods or GATT regulation on a change in the level of the tariff.

Assuming symmetry again, we have the fixed-effects model in (26) with year 
dummies ${ }^{14}$.

$$
\left\{\ln (1+t)_{i t}-0.5 \ln r_{i}\right\}=f_{i}+g_{t}+1 /(\sigma+\tau) \ln \left\{\left(L_{i t} / K_{i t}\right) c_{i} / a_{i} d_{i}\right\}
$$

where $f_{i}=1$ if i occurs, $f_{i}=0$ otherwise

$g_{t}=1$ if $\mathrm{t}=$ year of concern $(1970, \ldots, 1986), g_{t}=0$ otherwise.

In the first round, we assign the value for $\sigma=\tau=5$ which is obtained from the iterative OLS procedure, and generate values for other endogenous variables. The first-round fixed-effects model produces the coefficient on the right-hand side variable 0.099 . This in turn implies the second round starting values of $\sigma=\tau$ $=5.05$. We create the new data set and then estimate the fixed-effects model with year dummies again. We obtain the voter responsiveness parameter $\sigma=\tau=$ $5.05{ }^{15}$ This figure is very close to the one obtained through iterative OLS on pooled data for 1965.

We report the regression result in Appendix 3. Before calculating lobbying estimates from this regression, we again provide both the "economic" and "political" magnification elasticities in 1986 (Table 3). Overall "economic" and "political" elasticities are lower than in 1965. Magnification elasticities are significantly lower in the United States than those from the average.

We follow the same procedure to obtain lobbying estimates over trade policy as a percent of country GDP in 1986 (Table A3). Refer to Appendix 4 for the step-by-step calculation procedure.

\subsection{Validity and Reliability of the Results}

The average lobbying estimates over trade policy are measured at .8\% of GDP in 1986. The United States spent less than $0.2 \%$ of GDP for lobbying over trade policy in 1986. This is broadly consistent with Krugman (1990) and Feenstra (1992).

Appendix 3 reports estimates from the first and second-round fixed-effects model. We test the null hypothesis of equal country dummies with an $\mathrm{F}$ test. Under the null, the efficient estimator is a pooled least squares. The F ratio used

Table 3. Magnification Elasticities (1986).

\begin{tabular}{ccc}
\hline & Partial (Economic) & Political (General) Equilibrium \\
\hline$\frac{\text { Country mean }}{\text { Rentals }(K)}$ & $m \equiv(1-\alpha)(\alpha-\beta)+\gamma=8.25$ & $\mathrm{~m} / \sigma=1.63$ \\
Wages $(L)$ & $n \equiv \alpha /(\alpha-\beta)-\delta=9.21$ & $n / \tau=1.82$ \\
$\frac{\text { United States }}{\text { Rentals }(K)}$ & $m \equiv(1-\alpha)(\alpha-\beta)+\gamma=1.82$ & $\mathrm{~m} / \sigma=0.36$ \\
Wages $(L)$ & $n \equiv \alpha /(\alpha-\beta)-\delta=2.53$ & $n / \tau=0.50$ \\
\hline
\end{tabular}

14“ $P$ ” stands for country and “ $t$ " for year (1965-1986).

${ }^{15}$ Iteration does not improve the coefficient since it affects only $r, a, c$ and $d$, which are the same across time for each country. However, it does improve the estimates of the country dummies. This is due to the assumption that factor shares are constant during 1965-1986. 
for the test is $F(7,150)=12.43>2.01$ (critical value at 95\%), which implies that there exists heterogeneity in political institutions across OECD countries. Further, most of the country dummies are statistically significant ${ }^{16}$.

Lastly, we refer the reader here to Magee, Lee and Kim's [14] very recent 2019 paper showing that in a panel of advanced countries in the last two decades, protectionist lobbying as a percent of GDP increased but paradoxically, tariff rates fell. At the same time, the rise in country capital endowment ratios increased magnification effects for capital more than for labor. Tariffs fell too because the rates of return to lobbying rose more for capital than for labor.

\section{Ten Conclusions and Three Policy Recommendations}

Our results suggest that individual voters might be irrational a la Anthony Downs but voters as a group can be collectively rational. As Edmund Burke said, "The individual is foolish, but the specie is wise." As noted in the text above, interest-group competition in a democracy is weakly bounded anarchy, much like competitive markets. There is a tragedy of the commons problem in the US Congress resulting causing an absence of political property rights among groups. All lobbies prey on each other economically and on unrepresented voters. Here are our ten conclusions.

1) What is the biological reason for politics and lobbying? Humans are carnivores and fight over political and economic pecking orders like animals fight over dominance hierarches. Carnivores eat herbivores and herbivores eat herbs. Thus, we model politics and lobbying as non-cooperative win-lose games among competitive groups while economic transactions are win-win or cooperative games.

2) In general, we find that voters are highly rational. This contrasts with the rationally uninformed median voter effect cited in the political science literature.

3) We get an estimate of 5 for the equilibrium elasticity of protectionist campaign contributions with respect to our tariff variable $(1+t)$. Thus, voters react five times more negatively to an increase in our tariff variable than they do to increased protectionist campaign contributions.

4) This elasticity means that if our tariff variable $T=(1+t)$ increased by about $5 \%$ (e.g., 1.01 to 1.05 ), then the protectionist party must expend 25 percent more lobbying money to keep its probability of election unchanged. This relatively high number is partly explained by seven of the eight countries in our panel being advanced countries. All eight countries in the sample have more capital-intensive exports than import-competing production.

5) Tariff protection falls with economic development because of Magee Brock and Young's [1] endowment effect: capital accumulation a la Rybczynski shifts

\footnotetext{
${ }^{16}$ However, though not reported, some of the year dummies in the fixed-effects model are not statistically significant, but negative, which possibly indicates that the tariff rate underestimates the true protection for import-competing sectors. Random effects model is also estimated and produce a slightly higher figures for $\sigma$ and $\tau$. We prefer to use the fixed-effects model for the cross-country analysis, however.
} 
political power toward capital (the abundant factor) and away from labor (the scarce factor).

6) The other major driver of lobbying and rent seeking is production technology. The fraction of the national economy devoted to rent seeking increases with the "magnification elasticity" from international trade theory, which is the elasticity of factor rewards (wages and return to capital) with respect to product prices.

7) Ironically, the level of protectionist lobbying also increases with GDP per capita because factor price magnification effects increase as GDP per capita increases because the factor intensities of production in exportables and importables move closer together (intuitively, capital-labor ratios get more similar as countries become more capital abundant). While advanced countries have lower protection and more rational voters, they are prone to more redistributive lobbying conflict and rent seeking.

8) High magnification increases the fraction of the national economy devoted to rent seeking because it gives lobbying have a higher payoff. But as Magee, Lee and Kim [14] showed, growth with magnification leads to declining traded protection because capital lobbying increases faster than labor lobbying.

9) Increases in magnification make tariffs a more potent tool of redistribution, which may explain rising fights over tariffs. Our general equilibrium elasticities of factor prices with respect to product prices are 1.7 in the eight country panel and 0.4 in the United States.

10) Nevertheless, our estimate of the transaction costs of lobbying over protection is low: protectionist lobbying expenditures are about .2 of one percent for the United States and average one percent of GDP for the entire panel of eight countries. These are lower estimates than earlier estimates cited by Magee, Brock and Young [1] from Krugman and Feenstra for the US.

Policy recommendations are tricky in a general equilibrium democracy because of rational expectations.

Nevertheless, we offer three policy recommendations for the United States. First, enact US constitutional reform that would limit predatory redistributive lobbying. Second, impose costs on lobbyists faster than they can skirt the rules. Third, lawyers should be prohibited from lobbying or acting as lobbyists. Washington DC has ten times more lawyers per resident than the highest US state, New York, and they are the most effective lobbyists.

\section{Conflicts of Interest}

The authors declare there are no conflicts of interest regarding the publication of this paper.

\section{Errors in the Paper}

Dr Kwang Yeol-Yoo was unable to proofread the final manuscript and should not be held responsible for remaining errors or for the three sigma thoughts of 
the senior author on lobbying and politics. The views expressed in this paper also do not reflect the views of theFinancial Supervisory Service of the Government of Korea.

\section{References}

[1] Magee, S., Brock, W. and Young, L. (1989) Black Hole Tariffs and Endogenous Policy Theory: Political Economy in General Equilibrium. Cambridge University Press, New York

[2] Young, L. and Magee, S. (1986) Endogenous Protection, Factor Returns and Resource Allocation. Review of Economic Studies, 53, 407-419. https://doi.org/10.2307/2297636

[3] Magee, C. and Magee, S. (2004) The Madison Paradox and the Low Cost of Special-Interest Legislation. In: Nelson, D., Ed., The Political Economy of Policy Reform, Elsevier, New York, 131-154.

[4] Magee, S. (1993) Bioeconomics and the Survival Model: The Economic Lessons of Evolutionary Biology. Public Choice, 77, 117-132.

https://doi.org/10.1007/BF01049225

[5] Dorfman, S.S. (1958) Efficient Programs of Capital Accumulation. In: Linear Programming and Economic Analysis, McGraw Hill, New York, 331.

[6] Tullock, G. (1967) The Welfare Cost of Tariffs, Monopolies and Theft. Western Economic Journal, 5, 224-232. https://doi.org/10.1111/j.1465-7295.1967.tb01923.x

[7] Krueger, A. (1974) The Political Economy of the Rent Seeking Society. American Economic Review, 64, 291-303.

[8] Brock, W. and Magee, S. (1978) The Economics of Special Interest Politics: The Case of the Tariff. American Economic Review, 68, 246-250.

[9] Magee, C. and Magee, S. (203) The Effects of Rent Seeking on Economic Development: An Increasing Divergence Between Rich and Poor Countries? In: Ramaswamy, S. and Cason, J.W., Eds., Development and Democracy, Middlebury College Press, Hanover, 123-144.

[10] Becker, G. (1983) A Theory of Competition among Pressure Groups for Political Influence. Quarterly Journal of Economics, 98, 371-400. https://doi.org/10.2307/1886017

[11] Wittman, D.A. (1989) Why Democracies Produce Efficient Results. Journal of Political Economy, 97, 1395-1422. https://doi.org/10.1086/261660

[12] Barrow, R. (1999) The Determinants If Democracy. Journal of Political Economy, 107, 158-183. https://doi.org/10.1086/250107

[13] United Nations (1971) Classification of Commodities by Industrial Origin: Links between the Standard International Trade Classification and the International Standard Industrial Classification, Stat. Papers Series M, No. 43, Rev. 1.

[14] Mitchell, B.R. (1992) a. International Historical Statistics, Europe, 1750-1988, Stockton. b. International Historical Statistics-The Americas, Stockton. c. International Historical Statistics: Africa, Asia and Oceania, 1750-1988.

https://doi.org/10.1007/978-1-349-12791-7

[15] Magee, S., Lee, H. and Kim, J.Y. (2019) Evidence for the Tariff-Lobbying Paradox: Endogenous Tariffs Fall as Protectionist Lobbying Rises. Applied Economics, 51, 4368-4384. https://doi.org/10.1080/00036846.2019.1591604 


\section{Appendix 1}

Table A1. Factor shares by country.

\begin{tabular}{|c|c|c|c|c|c|c|c|c|}
\hline & \multicolumn{4}{|c|}{1965} & \multicolumn{4}{|c|}{1986} \\
\hline & alpha & beta & $m$ & $n$ & alpha & beta & $m$ & $n$ \\
\hline Australia & 0.5483 & 0.5005 & 10.12 & 11.16 & 0.5792 & 0.523 & 7.99 & 9.81 \\
\hline Austria & 0.5177 & 0.4653 & 9.59 & 9.27 & 0.444 & 0.4234 & 27.49 & 21.05 \\
\hline Canada & 0.51 & 0.474 & 14.11 & 167 & 0.5483 & 0.4974 & 9.37 & 10.27 \\
\hline Denmark & 0.5214 & 0.4948 & 18.92 & 19.54 & & & & \\
\hline Finland & 0.4889 & 0.4493 & 13.28 & 11.73 & 0.5626 & 0.4597 & 4.75 & 4.97 \\
\hline Greece & 0.6594 & 0.6498 & & & & & & \\
\hline Ireland & 0.4925 & 0.4664 & 20.04 & 18.42 & & & & \\
\hline Italy & 0.4678 & 0.4171 & 10.93 & 8.68 & & & & \\
\hline Netherlands & 0.5136 & 0.4202 & 5.67 & 4.97 & & & & \\
\hline Norway & 0.4803 & 0.4437 & 14.94 & 12.83 & 0.5002 & 0.3334 & 3.5 & 2.5 \\
\hline Spain & 0.594 & 0.5173 & 5.77 & 7.21 & 0.601 & 0.5327 & 6.34 & 8.3 \\
\hline Turkey & 0.7411 & 0.6739 & 4.37 & 10.56 & 0.7769 & 0.7242 & 4.73 & 14.24 \\
\hline USA & 0.5352 & 0.5274 & 58.63 & 66.38 & 0.6965 & 0.4669 & 1.82 & 2.53 \\
\hline \multirow{3}{*}{\multicolumn{2}{|c|}{ mean value }} & & 15.53 & 16.2 & & & 8.25 & 9.21 \\
\hline & & \multicolumn{4}{|c|}{$\operatorname{Avg}(65,86)$} & \multirow{2}{*}{$\mathrm{m}$} & \multirow{2}{*}{\multicolumn{2}{|c|}{$\mathbf{n}$}} \\
\hline & & & & \multicolumn{2}{|c|}{ beta } & & & \\
\hline \multicolumn{2}{|c|}{ Australia } & \multicolumn{2}{|c|}{0.5638} & & 8.89 & \multicolumn{2}{|r|}{10.34} \\
\hline \multicolumn{2}{|c|}{ Austria } & \multicolumn{2}{|c|}{0.4809} & 0.4 & & 14.72 & & 12.68 \\
\hline \multicolumn{2}{|c|}{ Canada } & \multicolumn{2}{|c|}{0.5292} & \multicolumn{2}{|c|}{0.4857} & 11.32 & & 11.67 \\
\hline \multicolumn{9}{|c|}{ Denmark } \\
\hline Finla & & \multicolumn{2}{|c|}{0.5258} & \multicolumn{2}{|c|}{0.4545} & 7.15 & \multicolumn{2}{|r|}{6.87} \\
\hline \multicolumn{9}{|c|}{ Greece } \\
\hline \multicolumn{9}{|c|}{ Ireland } \\
\hline \multicolumn{9}{|c|}{ Italy } \\
\hline \multicolumn{9}{|c|}{ Netherlands } \\
\hline \multicolumn{2}{|c|}{ Norway } & \multicolumn{2}{|c|}{0.4903} & \multicolumn{2}{|c|}{0.3886} & 5.51 & & 4.32 \\
\hline \multicolumn{2}{|c|}{ Spain } & \multicolumn{2}{|c|}{0.5975} & 0.5 & & 6.05 & & 7.74 \\
\hline Turl & & & & 0.6 & & 4.52 & & 12.17 \\
\hline US & & & & 0.4 & & 3.74 & & 4.69 \\
\hline
\end{tabular}

\section{Appendix 2}

Table A2. Trade lobbying as a percent of GDP calculations (1965 by iterative OLS).

\begin{tabular}{ccccccccc}
\hline A & B & C & D & E & F & G & H & I \\
\hline & ID & r & a & b & c & d & Ke/Ko(a/c) & Le/Lo(b/d) \\
\hline 1 & Australia & 1.128 & 1.1611 & 0.8642 & 5.6298 & 3.7013 & 0.206242 & 0.233486 \\
2 & Austria & 1.134 & 0.9711 & 1.0715 & 4.5456 & 5.2342 & 0.213635 & 0.204711 \\
3 & Canada & 1.113 & 0.9717 & 1.0852 & 3.9889 & 4.6572 & 0.243601 & 0.233016 \\
4 & Denmark & 1.096 & 1.088 & 0.9557 & 4.2941 & 3.5902 & 0.253371 & 0.266197 \\
5 & Finland & 1.119 & 0.8345 & 1.2591 & 3.3406 & 5.9667 & 0.249805 & 0.211021 \\
\hline
\end{tabular}




\section{Continued}

\begin{tabular}{|c|c|c|c|c|c|c|c|c|}
\hline \multicolumn{2}{|c|}{ Ireland } & 1.096 & 0.8693 & 1.2235 & 3.1565 & 5.0645 & 0.2754 & 0.241584 \\
\hline \multicolumn{2}{|c|}{ Italy } & 1.133 & 0.7255 & 1.4252 & 2.9986 & 7.8882 & 0.241946 & 0.180675 \\
\hline \multicolumn{2}{|c|}{ Netherland } & 1.163 & 0.881 & 1.1814 & 5.1507 & 8.0145 & 0.171045 & 0.147408 \\
\hline \multicolumn{2}{|c|}{ Norway } & 1.114 & 0.7678 & 1.2873 & 2.9031 & 5.9788 & 0.264476 & 0.215311 \\
\hline 11 & Spain & 1.155 & 1.2653 & $53 \quad 0.7524$ & 8.0888 & 3.7524 & 0.156426 & 0.200512 \\
\hline 12 & Turkey & 1.159 & 2.6873 & 0.3443 & 27.6089 & 1.2891 & 0.097335 & 0.267086 \\
\hline \multicolumn{2}{|c|}{ USA } & 1.047 & 1.5045 & 0.6759 & 5.7279 & 1.9486 & 0.262662 & 0.346864 \\
\hline \multirow[t]{2}{*}{$\mathrm{J}$} & K & & $\mathrm{L}$ & $\mathbf{M}$ & $\mathrm{N}$ & $\mathrm{O}$ & $\mathbf{P}$ & Q \\
\hline & K. shr & \multicolumn{2}{|c|}{ L. shr } & $\mathrm{H} * \mathrm{~K}$ & $I * L$ & $\left(H^{*} \mathrm{~K}+\mathrm{I}^{*} \mathrm{~L}\right)$ & ) $\mathrm{mfg} / \mathrm{gdp}$ & open(65) \\
\hline Australia & 0.5174 & \multicolumn{2}{|c|}{0.4826} & 0.10671 & 0.11268 & 0.21939 & 0.28 & 0.313 \\
\hline Austria & 0.4883 & \multicolumn{2}{|c|}{0.5117} & 0.104318 & 0.104751 & 0.209069 & 0.33 & 0.491 \\
\hline Canada & 0.4925 & & 075 & 0.119973 & 0.118256 & 0.238229 & 0.23 & 0.384 \\
\hline Denmark & 0.5067 & & 1933 & 0.128383 & 0.131315 & 0.259698 & 0.2 & 0.598 \\
\hline Finland & 0.4698 & & 302 & 0.117358 & 0.111883 & 0.229242 & 0.21 & 0.41 \\
\hline Ireland & 0.4737 & & 263 & 0.130457 & 0.127146 & 0.257602 & 0.28 & 0.784 \\
\hline Italy & 0.4427 & & 573 & 0.107109 & 0.10069 & 0.2078 & 0.23 & 0.272 \\
\hline Netherlan & 0.4619 & & 381 & 0.079006 & 0.07932 & 0.158326 & 0.29 & 0.831 \\
\hline Norway & 0.4553 & & 447 & 0.120416 & 0.11728 & 0.237696 & 0.21 & 0.833 \\
\hline Spain & 0.5207 & & 1793 & 0.081451 & 0.096105 & 0.177556 & 0.25 & 0.242 \\
\hline Turkey & 0.6951 & & 049 & 0.067658 & 0.081435 & 0.149092 & 0.16 & 0.146 \\
\hline USA & 0.5328 & & 672 & 0.139946 & 0.162055 & 0.302001 & 0.29 & 0.095 \\
\hline
\end{tabular}

\begin{tabular}{ccccc}
\hline & $\mathrm{N} * \mathrm{P} * \mathrm{Q}$ & $\mathrm{M} * \mathrm{P} * \mathrm{Q}$ & $\mathrm{O} * \mathrm{P} * \mathrm{Q}$ & $\mathbf{0 . 4}{ }^{*} \mathrm{~V}$ \\
\cline { 2 - 5 } $\mathrm{S}$ & $\mathrm{T}$ & $\mathrm{U}$ & $\mathrm{V}$ & $\mathrm{W}$ \\
\cline { 2 - 5 } & labor lob & cap lob & lobbying & lobbying 0.4 free ride \\
\hline Australia & 0.009875 & 0.00935 & 0.019227 & 0.0077 \\
Austria & 0.016973 & 0.0169 & 0.033875 & 0.0136 \\
Canada & 0.010444 & 0.0106 & 0.02104 & 0.0084 \\
Denmark & 0.015705 & 0.01536 & 0.03106 & 0.0124 \\
Finland & 0.009633 & 0.01011 & 0.019738 & 0.0079 \\
Ireland & 0.027911 & 0.02864 & 0.056549 & 0.0226 \\
Italy & 0.006299 & 0.0067 & 0.013 & 0.0052 \\
Netherlan & 0.019115 & 0.01904 & 0.038155 & 0.0153 \\
Norway & 0.020516 & 0.02106 & 0.04158 & 0.0166 \\
Spain & 0.005814 & 0.00493 & 0.010742 & 0.0043 \\
Turkey & 0.001902 & 0.00158 & 0.003483 & 0.0014 \\
USA & 0.004465 & 0.00386 & 0.00832 & 0.0033 \\
mean & 0.012388 & 0.01234 & $\mathbf{0 . 0 2 5}$ & $\mathbf{0 . 0 1 0}$
\end{tabular}


The following table provides estimates from the first and second-round fixedeffects model. We test the null hypothesis of equal country dummies with an $\mathrm{F}$ test. Under the null, the efficient estimator is a pooled least squares. The F ratio used for the test is $\mathrm{F}(7,150)=12.43>2.01$ (critical value at 95\%), which implies that there exists heterogeneity in political institutions across OECD countries. Further, most of the country dummies are statistically significant ${ }^{17}$.

\section{Appendix 3}

Table A3. Fixed-effects model with year dummies.

\begin{tabular}{lcc}
\hline & First-round Estimates & Second-round Estimates \\
\hline $1 /(\sigma+\tau)$ & $0.099(0.024)$ & $0.099(0.024)$ \\
\hline country dummy & $0.047(0.009)$ & $0.042(0.01)$ \\
1) Australia & $-0.048(0.017)$ & $-0.049(0.017)$ \\
2) Austria & $-0.005(0.01)$ & $-0.009(0.01)$ \\
3) Canada & $-0.001(0.004)$ & $-0.008(0.005)$ \\
4) Finland & $0.032(0.016)$ & $0.034(0.016)$ \\
5) Norway & $-0.062(0.023)$ & $-0.07(0.024)$ \\
6) Spain & $-0.026(0.064)$ & $-0.037(0.066)$ \\
7) Turkey & 0 & 0 \\
8) USA & $1.151(0.293)$ & $1.158(0.294)$ \\
Constant & 0.75 & 0.75 \\
Adj. $R^{2}$ & & \\
\hline
\end{tabular}

${ }^{\star}$ Standard errors are heteroskedacity-adjusted and reported in parenthesis. ${ }^{\star}$ USA is a benchmark case for the estimation of the fixed-effects model.

\section{Appendix 4}

Table A4. Trade lobbying as a percent of GDP (1986 by fixed-effects model).

\begin{tabular}{|c|c|c|c|c|c|c|c|c|c|c|c|}
\hline \multirow{2}{*}{ A } & B & C & D & E & F & G & $\mathrm{H}$ & I & $\mathrm{J}$ & $\mathrm{K}$ & $T$ \\
\hline & Country & a & b & c & d & $\mathrm{Ke} / \mathrm{Ko}$ & Le/Lo & K.shr(86) & labor shr & $G^{*} I$ & \\
\hline 1 & Australia & 1.2304 & 0.801 & 6.4196 & 3.4738 & 0.1917 & 0.2306 & 0.546 & 0.454 & 0.10465 & \\
\hline 2 & Austria & 0.7754 & 1.2808 & 2.9604 & 5.9766 & 0.2619 & 0.2143 & 0.4335 & 0.5665 & 0.11354 & \\
\hline 3 & Canada & 1.0424 & 0.9485 & 4.706 & 4.1187 & 0.2215 & 0.2303 & 0.5323 & 0.4677 & 0.11791 & \\
\hline 4 & Finland & 0.9421 & 1.0388 & 4.9908 & 5.7604 & 0.1888 & 0.1803 & 0.5334 & 0.4666 & 0.10069 & \\
\hline 5 & Norway & 0.7803 & 1.3034 & 4.5513 & 9.9406 & 0.1714 & 0.1311 & 0.3803 & 0.6197 & 0.0652 & \\
\hline 6 & Spain & 1.314 & 0.7289 & 8.3461 & 3.5065 & 0.1574 & 0.2079 & 0.5904 & 0.4096 & 0.09295 & \\
\hline 7 & Turkey & 3.3666 & 0.2919 & 38.835 & 1.0185 & 0.0867 & 0.2866 & 0.7543 & 0.2457 & 0.06539 & \\
\hline 8 & USA & 1.2788 & 0.8136 & 10.6 & 5.2655 & 0.1206 & 0.1545 & 0.4857 & 0.5143 & 0.0586 & \\
\hline
\end{tabular}

${ }^{17}$ However, though not reported, some of the year dummies in the fixed-effects model are not statistically significant, but negative, which possibly indicates that the tariff rate underestimates the true protection for import-competing sectors. Random effects model is also estimated and produce a slightly higher figures for $\sigma$ and $\tau$. We prefer to use the fixed-effects model for the cross-country analysis, however. 


\begin{tabular}{|c|c|c|c|c|c|c|c|c|}
\hline & $\mathrm{L}$ & $\mathbf{M}$ & $\mathrm{N}$ & $\mathrm{O}$ & $P=L^{*} N^{*} O$ & $Q=K^{*} N^{*} O$ & $\mathrm{R}=\mathrm{M}^{*} \mathrm{~N}^{*} \mathrm{O}$ & $S=0.4 * R$ \\
\hline Country & $\mathrm{H}^{*} \mathrm{~J}$ & $\left(G^{*} I+H^{*} J\right)$ & $\mathrm{mfg} / \mathrm{gdp}$ & open(86) & labor lob & cap lob & lobbying $r$ & lobby free ride \\
\hline Australia & 0.10468 & 0.2093328 & 0.17 & 0.347 & 0.0061754 & 0.00617319 & 0.01234854 & 0.0049 \\
\hline Austria & 0.12140 & 0.2349464 & 0.28 & 0.726 & 0.0246787 & 0.02308124 & 0.04775991 & 0.0191 \\
\hline Canada & 0.10771 & 0.225614 & 0.16 & 0.542 & 0.0093404 & 0.01022488 & 0.01956524 & 0.0078 \\
\hline Finland & 0.08414 & 0.1848327 & 0.25 & 0.522 & 0.0109808 & 0.01313985 & 0.02412066 & 0.0096 \\
\hline Norway & 0.08125 & 0.1464551 & 0.14 & 0.794 & 0.0090322 & 0.00724771 & 0.01627995 & 0.0065 \\
\hline Spain & 0.08514 & 0.1780959 & 0.27 & 0.376 & 0.0086438 & 0.00943647 & 0.01808029 & 0.0072 \\
\hline Turkey & 0.07042 & 0.1358073 & 0.25 & 0.383 & 0.0067424 & 0.00626111 & 0.01300355 & 0.0052 \\
\hline USA & 0.07947 & 0.1380628 & 0.2 & 0.181 & 0.0028767 & 0.00212116 & 0.00499787 & 0.0020 \\
\hline mean & & & & & 0.0098 & 0.0097 & 0.0195 & 0.0078 \\
\hline
\end{tabular}

